\title{
Fostering Experiential Learning And Service Through Client Projects In Graduate Business Courses Offered Online
}

\author{
Linda M. Hagan, Ph.D., Walsh College, USA
}

\begin{abstract}
Undergraduate marketing and public relations capstone courses utilize client projects to allow students to apply their knowledge and encourage collaboration. Yet, at the graduate level, especially with courses offered in an online modality, experiential service learning in the form of client project assignments presents unique challenges. However, with an increased emphasis on practical application across the business curricula and growth in distance learning, client projects can provide opportunities for adult learners to hone their skills and encourage teamwork using new collaborative technology. This paper discusses experiential service learning and gives an example of a client project model.
\end{abstract}

Keywords: Client Projects; Service-Learning; Experiential Learning; Distance Learning; Graduate Business Education; Adult Learners; Communication; and Public Relations (PR)

\section{INTRODUCTION}

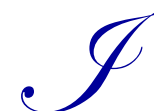

$\mathrm{t}$ is typical practice of many undergraduate marketing and public relations capstone courses to incorporate client projects, which give students the opportunity to apply their knowledge by producing actual deliverables while also encouraging teamwork and networking. Yet, at the MBA level, especially in distance learning courses, experiential service-learning opportunities in the form of client project assignments are not as popular and present challenges for students, instructors, and clients. In recent years, more business school programs are implementing experiential learning models into the curricula as a way for students to get real-world experience within the classroom.

Although others have written about the pedagogy of client projects as experiential and service learning models at the undergraduate level, this paper discusses the practice in graduate business courses delivered through distance learning and identifies project elements assigned in a graduate level strategic communications course. Based on student feedback, observation, and anecdotal evidence, client projects promote lessons in interpersonal communication among teammates, professional communication with clients, mediated communication utilizing new technology, and strategic communication to various stakeholders of an organization through traditional formats as well as social media.

\section{THE VALUE OF EXPERIENTIAL LEARNING OPPORTUNITIES:}

Much has been written about experiential learning since scholar David A. Kolb was credited with developing the model of experiential learning in the 1970s based off the work of John Dewey, Kurt Lewin, and Jean Piaget. Kolb for the following 40 years, along with Roger Fry, continued to study experiential learning as a continuous spiral of four elements including "(1) concrete experience followed by (2) observation and experience followed by (3) forming abstract concepts followed by (4) testing in new situations" (Smith, 2001, para. 6). Peter Jarvis in the 1990s used Kolb's model to further study adult learners and their learning processes. Through the years, many others have studied experiential learning, with some offering different definitions (Smith, 2001). A common theme, however, is that experiential learning is learning from direct, hands-on experience. 
McHann \& Frost (2010), in their comprehensive review of experiential learning theorists, cited David Garvin's (2000) learning process of acquiring information, interpreting information, and then applying information along with Dr. W. Edward Deming's "learning by doing" model from his work with the Japanese after World War II to present an argument on the value and the need for experiential learning in business schools where students learn by doing. McHann and Frost (2010) said:

To the extent this is true, i.e., that 'learning requires action,' then to that same extent our efforts to help students learn and prepare for their professional careers must find ways to infuse action into their learning. Most of our classes do a good job of helping students acquire information. Some classes even go further and help students interpret information in a relevant, meaningful way to their individual or organizational situation. But few classes focus upon helping them learn to actually apply what they are studying. And yet, we have evidence from business history and experience that a focus upon application can produce amazing learning, improvement, productivity, and success. (p. 5)

Although there is growing consensus in business schools that experiential learning activities give students direct learning opportunities, and according to McCarthy and McCarthy (2006) "are among the most powerful teaching and learning tools available" (p. 204), there are varying ways for educators to give students the experience, ranging from case studies, living case studies, internships, job shadowing, and other hands-on, classroom-based activities.

\section{REAL CLIENT PROJECTS AS EXPERIENTIAL LEARNING ACTIVITIES}

To get the maximum benefit of experiential learning, educators need to go further than case studies or working with hypothetical examples. Students should assume the role of key decision makers by working with real clients on real client projects. Experiential learning models in the form of client projects are especially popular in many undergraduate capstone marketing courses because they allow students to demonstrate their accumulated knowledge over the course of their education. Experiential learning gives students a sense of accomplishment by pulling together all they have learned and putting it into action.

Many educators (Aldoory \& Wrigley, 2000; Benigni, Cheng, \& Cameron, 2003; Cooke \& Williams, 2004; Fitch, 2011; Lopez \& Lee, 2005; Melton \& Hicks, 2011) have studied various aspects of incorporating client projects into the classroom. Aldoory and Wrigley (2000) found that the use of real clients in undergraduate PR campaigns courses had positive rewards for students such as an application of theory in practice, motivation, management skills such as strategic planning, and professionalism. Aldoory and Wrigley (2000) though noted that client projects "take more effort on the part of teachers while also offering more learning to the student" (p. 55). Clients, too, "valued the work...in terms of new perspectives, ideas, and time" and most importantly "forced [them] to reflect on what they do and to justify their approaches to the students" (Aldoory \& Wrigley, 2000, p. 52).

Although client projects have strong support, projects done by groups of students can be problematic. McCorkle, Reardon, Alexander, Kling, Harris, and Iyer (1999) indicated along with the "good," there is some "bad" and "ugly," and identified problems inherent in any classroom-based group project, specifically free riding/social loafing, inadequate reword, skill and attitude problems, transaction-costs problems, and integrative learning problems (pp. 108-109).

Despite possible disadvantages, the advantages to real client projects are outweighed by the learning opportunity for students and professors. Cooke \& Williams (2004) found that although client projects "require professors to venture into unchartered territory," instructors "get to experience the exhilaration of coaching students through a project" (Cooke \& Williams, 2004, p. 150). With the client project, the instructor takes on the role of supervisor and coaches students on the class project, simulating a real-world, business entity. Real client projects offer students not only experiential learning, but collaborative and cooperative learning experiences that cannot be duplicated in the classroom.

Cooke and Williams (2004) noted that some business schools, such as Clemson University, have developed academic consultancy services where for-profit clients pay for the work of students, while other universities, like the 
University of Texas, work with for-profit clients, but not for pay. Cooke and Williams (2004) concluded that "whatever the approach, client projects facilitate communication between academia and business" and "offer opportunities for students to gain practical experience that surpasses any classroom simulation or case study, and keep instructors in touch with business trends and practices" (p. 139).

\section{STUDENTS LEARN TO SERVE THE COMMUNITY}

Related to experiential learning, but not synonymous, is service learning. Service learning engages students in learning by doing while at the same time providing service to the community. Angelidis, Tomic, and Ibrahim (2004) noted service learning as a "pedagogy that links community service with academic experience" that can be defined as "learning by utilizing course assignments that give the opportunity to students to apply knowledge and skills taught in the classroom to projects benefiting the community" (p. 2). Service learning can raise students' awareness of community issues and teach students valuable life-long lessons about the personal rewards of philanthropy. Legal, marketing, and technology professionals traditionally have engaged in pro bono work, where they do work for the public good without pay. It is a growing trend by companies, such as global pharmaceutical company GlaxoSmithKline, to actively encourage employees to participate in pro bono work (Kapulnik, 2012).

In recent years, many educators (Angelidis et al., 2004; Andrews, 2007; Giunta, 2008; Godfrey, Illes, \& Berry, 2005; Hoxmeier \& Lenk, 2003) outlined service learning models for courses across the business disciplines, especially in strategic management and information systems courses. Hoxmeier and Lenk (2003) suggested that "student learning outcomes include deep learning of the course technical knowledge, improved interpersonal communication skills, more effective client and project management skills, and an enhanced societal sensitivity for the value of their information systems knowledge to their community" (p. 91) when information systems students engaged in community projects. Godfrey et al. (2005) argued "service-learning pedagogy and the associated educational experiences provide a partial solution to the significant problem of narrowness in business education" and "the four Rs of service-learning: Reality, Reflection, Reciprocity, and Responsibility each yield a broader educational and experience base for students" (p. 309) while providing academic rigor.

This author has had success in incorporating service learning client projects, in particular projects designed to help charitable organizations, especially those serving disadvantaged children. In service learning projects, the students partner with community or non-profit organizations to provide services pro bono that the organization usually could not afford to purchase.

\section{THE CHALLENGE FOR GRADUATE BUSINESS PROGRAMS}

While there is widespread use of experiential learning models at the undergraduate level, they are not as popular at the graduate level, especially for hybrid or online courses, perhaps because they have presented many unique challenges for students, instructors and clients. The reason for this is at the graduate level there are a higher percentage of adult learners. Adult learners typically are students who need to balance schoolwork with a full-time job, families, and other responsibilities. At the MBA level, students have varied backgrounds and experiences and may live far from the main college location. The combination of adult leaner schedules with the growth of online and evening class offerings makes it increasingly difficult for students to get together to work on team projects.

Distance learning, however, is growing exponentially at some colleges and universities across the nation. According to Brooks (2012) in an editorial column in The New York Times, some of the nation's elite universities are "moving aggressively online" (para. 3). According to a 2011 survey conducted by the Babson Survey Group in collaboration with the College Board:

Over 6.1 million students were taking at least one online course during the fall 2010 term, an increase of 560,000 students over the previous year. The 10\% growth rate for online enrollments far exceeds the $2 \%$ growth in the overall higher education student population. Thirty-one percent of higher education students now take at least one course online. (The Sloan Consortium, 2012, para. 5) 
Brooks (2012) questioned how business schools are "going to blend online information with face-to-face discussion, tutoring, debate, coaching, writing and projects?" (para. 10). Because of this steady increase in online courses, business schools need to devise methods to give students experiential learning opportunities. Yet, to do so with team projects, poses challenges. Fortunately, there are many online collaborative software programs available, many of which are used in industry. Students are using products offered by Skype, Apple, Cisco Systems, and Adobe to have virtual meetings with classmates. Some online conferencing tools have free trial periods, which allow students to try out the technology for free. Online learning management systems offer ways for students to share and edit documents in a protected virtual space. Students are able to collaborate, too, in presentations either through synchronous delivery or asynchronous taping and posting on Internet sites such as YouTube.

\section{A CLIENT PROJECT MODEL FOR USE WITH GRADUATE STUDENTS}

This paper will now discuss one experiential, service-learning client project used in a graduate level marketing course on strategic communication and public relations offered as an elective in the MBA program of a private, not-for-profit business college. Students who enroll in the course specialize in marketing, management, finance, and information systems. The students are non-traditional adult learners with business experiences that range from young professionals to entrepreneurs to senior managers across industries. Because of the variation in age and business practice, the computer skill level when it comes to using collaborate software, virtual conferencing, presentation development, and social media use varies greatly. As a result, students are increasing their technology literacy by learning from each other. The client project challenges students to determine strategies in order to communicate with the various stakeholders of an organization through the use of traditional media and social media.

During the semester, students are introduced to the field of public relations from both a strategic management and marketing perspective. Students have the opportunity to put their public relations knowledge into practice by working with a nonprofit organization through a mock agency/class client relationship. Throughout the semester, students are introduced to various aspects of public relations campaign development and develop sections of a client campaign project throughout the course. A major aspect of the client project is to develop a social media campaign demonstrating to the client how to gain a presence on Facebook, Twitter, YouTube, or other social media outlets.

As the final graded project, each team (acting as a PR agency) develops a high quality, public relations campaign for a charitable organization based on the research and strategic planning the group conducts during the semester. The final deliverable includes a written/visual pitch book and voice-over PowerPoint presentation. Teams submit their campaign project (one comprehensive project per team) to the class site for grading by the professor. In addition, teams forward their campaign to the client to use.

Following are some examples of the key activities and assignments for developing a successful client engagement project.

\section{Selection of the Client - Instructor Responsibility}

The instructor needs to be involved in the client selection. Most business instructors have the professional connections, credibility, and experience to select the "right" client. Lopez and Lee (2005) suggested tips on identifying, recruiting, and selecting appropriate clients for client-based projects. An advantage of working with nonprofit organizations is that they typically do not have the budget or programs in place to do the work on their own. The project challenges students to learn how to communicate effectively to various stakeholders to raise awareness of issues, seek funding, and educate - all on a shoestring budget. The instructor also is responsible for establishing the point of regular contact between the student designated as "account director" for each team (limiting the number of students contacting the client) and the organization. In their study on the role of clients in class projects, Benigni, Cheng, and Cameron (2003) found that client involvement led to "more positive course outcomes" (p. 1).

As noted earlier, graduate student satisfaction of service learning projects have been greatest with clients that serve children, especially those disadvantaged because of economic inequities. Some examples of clients in the 
past few years have included a nonprofit that obtains cost-free dental care for inner city children, a youth afterschool sports program for urban children, an educational partnership program that teams prosperous suburban schools with economically disadvantaged school children, and a program that works with volunteers who serve as court appointed special advocates for foster children. Only one student in the author's years of running the class has balked at having to pay tuition to provide pro bono work, albeit to a nonprofit for children. The majority of graduate students are more than willing to provide their services and view it not only as a learning experience but also an opportunity for philanthropy.

In a formal engagement letter sent by the instructor thanking the client for agreeing to serve as class client, the instructor explains that the students will be working on the project virtually via an online classroom-learning environment. In addition, the instructor outlines the scope of work and the benefits for the organization as being a class client. One salient point that appeals to clients besides getting "free" ideas is that adult students, who may not have otherwise known about the charity, become aware of the good work of the organization. The letter discusses what is needed by the organization: the willingness and enthusiasm of the organization's top leadership and board members to allow students to work with the organization and the name and contact information for the key client contact along with a few staff or board members and adult clients or donors. In addition, the instructor asks the client to send a brief e-mail to all staff and board members notifying them of the student project. Since the charitable organizations deal with children, students are instructed that they may not contact any children directly and may only observe services with the expressed permission and oversight of the key client contact.

\section{Team Formation}

At the graduate level, especially in MBA programs, the professional experiences of students can vary greatly. Teams can be formed in one of three ways: Students self-select teammates, instructor randomly forms teams, or the instructor develops teams based off a mix of talents. Although some students prefer self-selection, the instructor can remind students that in the business world, rarely do people get to pick their own work teams. Ideally, the instructor forms the teams by mixing specializations or professional experiences (i.e., marketing professionals with IT professionals with management professionals and those who have worked for corporate and nonprofit organizations) based off biographical information shared with the instructor during the first week of class. Ultimately, the best scenario is a diversity of team members so students learn from each other and learn from doing. Additionally, the size of the team matters as well, with three to four members per team as most ideal.

\section{Team Member Introductions}

Once the client project teams are formed and announced to students during the second week of class (after the drop/add deadline), students are instructed to introduce themselves to their teammates through the online course discussion board. In the "getting to know you" exercise, students upload their professional biographies or write a brief description of their academic and professional work experiences. The instructor should encourage students to further get to know one another by sharing information about the type of worker they are and their personal strengths and weaknesses. For example, the instructor posts questions to team members such as, "Are you someone who likes to work in advance of deadlines? Or, are you someone who likes to work on deadline? Would you describe yourself as analytical or more of a creative type? Do you prefer to lead and manage team projects or rather be assigned tasks? Do you like to work closely and meet regularly with teammates or work independently? Do you think you are a good writer or an editor or do find written communication a weakness? Are you good with technology, such as PowerPoint, Excel, and iMovie?" In addition, the instructor asks students to discuss some of their initial concerns about a team project, especially one in an online course that makes up a substantial amount of their final course grade.

Around the same time, the instructor discusses the developmental sequence of group dynamics developed by Bruce Tuckman in 1965. Tuckman's research showed that groups naturally evolve through four stages: forming, storming, norming, and performing. Although adult learners, the instructor reminds students to act professionally in their working relationships with one and other and practice persuasion, negotiation and compromise tactics to work together throughout the project, but especially during the "storming" period. 


\section{Team Work Plan}

During week three, students are encouraged to "meet" virtually (utilizing any number of electronic or phone conferencing tools), or through simple e-mail to discuss the team client project and develop the work plan assignment due in week four. Depending on the geographic locations of students, some student teams manage face-to-face meeting times periodically through the semester, despite the online modality of the course.

The work plan requires an understanding of the expectations of the team project assignment and only cursory research on the client at this time. The work plan is the team's action plan to complete the client project, which is a request for proposal (RFP) by the client. The plan provides an overview of the project, a listing of the required activities, determination of how the team will divide activity responsibilities, and a working schedule that includes your team's established due dates.

An important aspect of the work plan is the division and assigning of responsibility of tasks fairly. The division of duties can vary depending on the skills of individual team members; however, students are reminded that the editing of the final document should be the responsibility of every team member since the team will lose points for poor writing, including grammar, spelling, and punctuation errors. Teams are encouraged to assign titles for each member that reflects their function on the team, such as account director, research director, creative director, information technology director, and specialty roles such as public information director or social media director.

The work plan template shown below follows a format recommended by Mary Ellen Guffey (2008) in her book titled, Business Communication (pp. 320-321).

\begin{tabular}{|c|c|}
\hline & $\begin{array}{c}\text { PR } \frac{\text { Work Plan }}{\text { Agency Name }} \\
\text { Names of Each Team Member followed by Mock Title }\end{array}$ \\
\hline Background: & Provide a brief paragraph on the client and statement of problem/opportunity \\
\hline $\begin{array}{l}\text { Statement of } \\
\text { Purpose: }\end{array}$ & Provide a brief paragraph on the initial purpose of campaign, the scope and limits of the project \\
\hline $\begin{array}{l}\text { Outline of } \\
\text { Campaign Project: }\end{array}$ & $\begin{array}{l}\text { List all elements needed for the project matching the expectations shown on the grading rubric for the } \\
\text { client project. Additionally, tentatively assign names of person(s) responsible for each section (you } \\
\text { can include the team member's name in parentheses after each item). }\end{array}$ \\
\hline Work Schedule: & $\begin{array}{l}\text { Provide a schedule that estimates the time needed to complete all of the project tasks. Don't forget to } \\
\text { build in time for editing and revising the written project and putting together the presentation. Give } \\
\text { actual deadlines or date ranges (i.e., Month day, year or indicate during Week 6.) }\end{array}$ \\
\hline
\end{tabular}

Only one work plan document is needed per team; however, each team member must upload that document to his or her assignment area to earn credit for the assignment. This is to ensure that each teammate has participated in the development of the work plan and is in agreement of the plans outlined and the responsibilities of duties.

\section{Team Progress Report}

During week eight of the class, student teams produce a progress or interim report, which in practice is used to inform supervisors on the status of a project (Guffey, 2008). The purpose of the progress report (and assignment expectations) is to provide the supervisor (instructor) with evidence that the team is making progress. In a class environment, the progress report serves as checkpoint and alerts the instructor of any issues. As with the work plan, team members collaborate and write one progress report; however, each team member must upload the copy of the progress report to his or her own assignment area to earn the grade. This ensures that all team members approve of the content.

The progress report template shown below follows a format recommended by Mary Ellen Guffey (2008) in her book titled, Business Communication (pp. 369-371). 


\begin{tabular}{|c|c|}
\hline & $\begin{array}{l}\qquad \frac{\text { Team Progress Report }}{\text { PR Agency Name }} \\
\text { Names of Each Team Member followed by Mock Title }\end{array}$ \\
\hline Introduction & Review the purpose and background of the project. \\
\hline $\begin{array}{l}\text { Work } \\
\text { Completed: }\end{array}$ & Provide a brief paragraph on the work you have completed and who completed it. \\
\hline $\begin{array}{l}\text { Work in } \\
\text { Progress: }\end{array}$ & Provide a brief paragraph on the work in progress and work yet to be completed, and who is responsible for it. \\
\hline $\begin{array}{l}\text { Anticipated } \\
\text { Problems: }\end{array}$ & $\begin{array}{l}\text { Alert your instructor of any anticipated problems or concerns that could potentially limit your successful } \\
\text { completion of a high quality product. Discuss possible solutions. }\end{array}$ \\
\hline $\begin{array}{l}\text { Group } \\
\text { Dynamics: }\end{array}$ & $\begin{array}{l}\text { Provide a brief paragraph assessing the dynamics of your team thus far through the project. Alert your } \\
\text { instructor of any issues. Discuss the progress each individual team member is making and your progress as a } \\
\text { team. Offer an honest evaluation. If someone has not been participating, say that and why that has been the } \\
\text { case. }\end{array}$ \\
\hline Closing: & Provide a concluding paragraph that includes the targeted completion date. \\
\hline
\end{tabular}

\section{Client Deliverable}

In week ten, the final client written project is due. The major contents of the public relations proposal includes a situation analysis, positioning \& resource considerations; problem statement; secondary research findings (given the short semester, students are not expected to do primary research); development of goals, objectives, messages, strategies, and tactics; timeline; budget (estimated realistically); and measurement and evaluation strategies. The appendix section includes some examples of the creative elements such as news releases or web site changes. The instructor provides students with detailed expectations along with a grading rubric. Each team member is expected to upload the final written deliverable individually to the class site (again to ensure each team member approves the final project), although some teams have chosen to mail a hard copy to the instructor in order to ensure quality color and formatting.

\section{Presentation to Client}

In addition to a written deliverable, students produce a presentation highlighting only the key information listed above as a pitch to the client. In the "real-world" presentations to clients typically are formal and done face-toface, but because of the online nature of the course, students tape their sections individually (each contributing fairly to the presentation), combine the sections, and then upload it to the class site. Some teams have posted on YouTube or mailed the instructor the presentation in a flash drive format.

\section{Peer/Self/Team Evaluation}

The final deliverable for the project is a peer/self/team evaluation form. Each student is expected to submit an evaluation of each team member's contribution (including him or herself). A template of an evaluation form is provided in the online course tool for downloading. In addition, students must write a comment under each name indicating how much the person contributed to or hindered the success of the team. Students are asked to consider each member's participation, fair workload, and quality of work. Students are assured that all comments will be kept confidential by the professor. At the bottom of the page, students evaluate the grade they think their team should earn on the overall project. This exercise fosters reflective learning.

\section{Feedback to Students from Client}

To make the project as real as possible, clients are encouraged to provide feedback to the students once they have reviewed the projects. Typically, clients take a few weeks to go through the team projects, sometimes reviewing the projects with their board of directors. In every case, clients have provided a written summary of their comments, praising the quality of the students' work and creative approaches. Some clients have indicated specific elements of the proposals that they plan to implement and why. 


\section{RECOMMENDATIONS FOR FUTURE RESEARCH}

This paper was based on anecdotal evidence obtained from informal student and client feedback, course/instructor evaluations, observation, and reflection on the author's experiences coaching graduate students on client projects in an online environment. As such, the author concludes that real client projects taken on as part of a service learning activity provides rich experiences for students. However, findings from Fitch (2011) "revealed that assumptions cannot be made about the value of real-client projects" and suggested "that learning activities need to be carefully structured to make the link between academic learning and professional development explicit and beneficial (p. 491). Hence, empirical research is needed to evaluate effectiveness of pedagogical methods, assessment of student learning outcomes, application of business practices, and satisfaction of business clients. Strategies on better ways to facilitate the practical application of client projects across all business disciplines would be helpful. Additionally, more pedagogical discussions are needed among faculty colleagues through college faculty development workshops and at academic conferences.

\section{CONCLUSION}

Although client projects may not be right for every class or instructor, client projects provide students a rich opportunity to test their communication skills, and learn by doing. With the proliferation of online courses, business professors need to incorporate different strategies, albeit somewhat traditional models, for practical application of business content in their online classes. Client projects for online graduate courses promote team work and collaboration, furthers communication skill-building, teaches students how to utilize new technology, and gives students the opportunity to contribute to their communities through service-learning.

\section{AUTHOR INFORMATION:}

Linda M. Hagan, Ph.D., is Director of the Doctor of Management in Executive Leadership program at Walsh College, in Troy, Michigan. She teaches courses in business and strategic communication. She has taught at Michigan State University, Syracuse University, and the University of Maryland. Prior to academia, Dr. Hagan worked in corporate communications in the automotive industry. She is Accredited in Public Relations (APR) and an active member of the Public Relations Society of America Detroit Chapter. She earned her Ph.D. from the University of Maryland, a master's degree from the University of Arizona, and a B.B.A. from Eastern Michigan University. E-mail: lhagan@walshcollege.edu

\section{REFERENCES}

1. Aldoory, L., \& Wrigley, B. (2000, Winter). Exploring the use of real clients in the PR campaigns course. Journalism \& Mass Communication Educator, 54(4), 47-58.

2. $\quad$ Andrews, C. P. (2007, September/October). Service learning: Applications in business. Journal of Education for Business, 83(1), 19-26.

3. Angelidis, J., Tomic, I., \& Ibrahim, N. A. (2004, Spring). Service-learning projects enhance student learning in strategic management courses. Review of Business, 25(2). Retrieved from http://www.freepatentsonline.com/article/Review-Business/119108640.html

4. Benigni, V., Cheng, I, \& Cameron, G. T. (2003). The role of clients in the public relations campaigns course. A paper submitted to the Teaching Public Relations Division of the 2003 Association for Education in Journalism and Mass Communication Conference in Kansas City, MO.

5. Brooks, D. (2012, May 3). The campus tsunami. The New York Times, The Opinion Pages. Retrieved from http://www.nytimes.com/2012/05/04/opinion/brooks-the-campus-tsunami.html

6. Cooke, L., \& Williams, S. (2004, June). Two approaches to using client projects in the college classroom. Business Communication Quarterly, 67(2), 139-152. doi:10.1177/1080569904265321

7. Godfrey, P. C., Illes, L. M., \& Berry, G. R. (2005, September). Creating breadth in business education through service-learning. Academy of Management Learning \& Education, 4(3), 309-323

8. Fitch, K. (2011). Developing professionals: Student experiences of a real-client project. Higher Education Research \& Development, 30(4), 491-503. doi:10.1080/07294360.2010.527930 
9. Garvin, D. A. (2000). Learning in action: A guide to putting the learning organization to work. Boston, MA: Harvard Business School Press.

10. Giunta, C. (2008). A service learning model for management students. Academy of Business Education Annual Conference Proceedings, USA, 9.

11. Godfrey, P. C., Illes, L. M., \& Berry, G. R. (2005, September). Creating breadth in business education through service learning. Academy of Management Learning \& Education, 4(3), 309-323.

12. Guffey, M. E. (2008). Business communication: Process \& product $\left(6^{\text {th }}\right.$ ed.). Mason, OH: South-Western Cengage Learning.

13. Horwitz, F. (2010, May/June). Transforming the business school. BizEd, 34-39. Retrieved from http://www.aacsb.edu/publications

14. Hoxmeier, J., \& Lenk, M. M. (2003). Service-learning in information systems courses: Community projects that make a difference. Journal of Information Systems Education, 14(1), 91-100.

15. Kapulnik, T. (2012, April 5). Experiential learning: Employees develop through pro bono - A case study of GlaxoSmithKline's PULSE volunteer partnership [Web log post]. Retrieved from http://www.taprootfoundation.org/blog/2012/04/experiential-learning-employee.php

16. Kolb, D. A. (1984). Experiential learning. Englewood Cliffs, NJ: Prentice Hall.

17. Lopez, T. B., \& Lee, R. G. (2005, August). Five principles for workable client-based projects: Lessons from the trenches. Journal of Marketing Education, 27(2), 172-188. doi:10.1177/0273475305276840

18. McCarthy, P. R., \& McCarthy, H. M. (2006, March/April). When case studies are not enough: Integrating experiential learning into the business curricula. Journal of Education for Business, 81(4), 201-204.

19. McCorkle, D. E., Reardon, J., Alexander, J. F., Kling, N. D., Harris, R. C., \& Iyer, R. V. (1999, August). Undergraduate marketing students, group projects, and teamwork: The good, the bad, and the ugly? Journal of Marketing Education, 21(2), 106-117. doi:10.1177/0273475399212004

20. McHann, J. C., \& Frost, L. A. (2010, August). Integrating experiential learning into business courses: Using learning journals to create living case studies. American Journal of Business Education, 3(8), 1-12.

21. Melton, J., \& Hicks, N. (2011). Integrating social and traditional media in the client project. Business Communication Quarterly, 74(4), 494-504. doi:10.1177/1080569911423959

22. Smith, M. K. (2001). David A. Kolb on experiential learning. The Encyclopedia of Informal Education. Retrieved from http://www.infed.org/b-explrn.htm

23. The Sloan Consortium. (2012). Going the distance: Online education in the United States, 2011. Retrieved from http://sloanconsortium.org/publications/survey/going_distance 2011

24. Tuckman, B. W. (1965). Developmental sequence in small groups. Psychological Bulletin, 63(6), 384-399. 
NOTES 